\title{
Towards sustaining the status quo: Business talk of sustainability in Finnish corporate disclosures 1987-2005
}

"Accepted author manuscript" version (postprint)

\author{
Matias Laine \\ University of Tampere \\ Correspondence with the author: \\ Matias Laine \\ School of Management \\ FIN-33014 University of Tampere \\ Finland, Europe \\ e-mail: Matias.Laine(at)uta.fi
}

\section{Reference to the original publication:}

Laine, M. (2010), Towards sustaining the status quo: Business talk of sustainability in Finnish corporate disclosures 1985-2005, European Accounting Review, 19(2), 247-274.

\section{http://doi.org/10.1080/09638180903136258}

This is an accepted author manuscript version of an article whose final and definitive form has been published in the European Accounting Review

Acknowledgements: The author is grateful for the constructive comments provided on earlier versions of the paper by Editor Salvador Carmona, two anonymous reviewers, Salme Näsi, Hannele Mäkelä, Oana Apostol, Nelson Phillips and the participants of the parallel sessions at the $18^{\text {th }}$ IABS Annual Congress in Florence, June 2007; the $31^{\text {st }}$ EAA Annual Congress in Rotterdam, April 2008; and the $2^{\text {nd }}$ Conference on Qualitative Research Methods in Vaasa, May 2008. An early version of this paper appeared in the proceedings of the $18^{\text {th }}$ IABS Annual Congress. Moreover, the help of Johanna Heiskanen with the data analysis and of Virginia Mattila with the English language is gratefully acknowledged. This research is a part of the RespMan Project, funded by the Liike2 Research program of the Academy of Finland. Financial support was also generously provided by the Finnish Graduate School of Accounting, Finnish Foundation of Economic Education (Liikesivistysrahasto) and the Marcus Wallenberg's Foundation for Business Studies. The usual caveat applies. 


\title{
Towards sustaining the status quo: Business talk of sustainability in Finnish corporate disclosures 1987-2005
}

\begin{abstract}
The paper seeks to shed more light on how businesses have used the language of sustainability in their disclosures. The study employs interpretive textual analysis and takes a closer look at how the corporate talk of sustainability has developed in the disclosures of three major Finnish companies during the period 1987-2005. In-depth understanding is sought by limiting the analysis of disclosures from four anchor points only. The findings indicate major changes in the ways the case corporations have used sustainability-related concepts over the two decades. Over time sustainability seems to have transformed from a possibly revolutionary concept into an evolutionary one, if not to one merely concerned with sustaining of status quo. Moreover, whereas in the early disclosures the conceptualization of sustainability appears to be rather polyphonic, in more recent years the companies use fairly similar rhetoric drawing on the discourse of weak sustainability. As a longitudinal study the paper makes a contribution to the still relatively limited body of research deconstructing corporate social and environmental disclosures from an interpretive standpoint. However, the study focuses only on the disclosures of three case companies in one particular country, and thus the generalization of the findings must be approached with caution.
\end{abstract}

Keywords: sustainable development, sustainability, corporate disclosures, longitudinal study, Finland

\section{INTRODUCTION}

During the last two decades the concept of sustainable development has established itself as a prominent idea on both the global and the local levels. Originally, the Brundtland Commission (UNWCED, 1987) deliberately gave sustainable development a vague meaning, since this helped the concept to gain broader acceptance (Reid, 1995). However, the elasticity quickly transformed into blurriness as various social actors proposed and subsequently applied their own definitions of the concept (e.g. Léle, 1991; see also Redclift, 1987). Indeed, Bebbington (2001: 129) has pointed out that "sustainability means different things to different people in different contexts". Nevertheless, sustainable development enjoys widespread acceptance as an appropriate goal for humankind, even though there is no common understanding regarding what this elusive goal actually is and how it could be achieved (e.g. Gray, 2009; Meadowcroft, 2000; Reid, 1995; Robinson, 2004).[1]

The business sector is considered to have a crucial role as the global society aspires to sustainability (Holliday et al., 2002; Porritt, 2005). Accordingly, an increasing number of companies are publishing different kinds of sustainability and corporate social responsibility reports (KPMG, 2008). Through these disclosures business actors disseminate their views on environmental and social issues as well as on sustainable development in general. Since these organisations are very powerful social actors the 
disclosures also construct reality (Phillips and Hardy, 2002) and affect how society at large perceives sustainability (see also Hines, 1988).

The significance of corporate non-financial environmental disclosures, and of carbon reporting in particular, appears to be growing due to increased concerns about the impacts of global climate change (Bebbington and Larrinaga-González, 2008; Kolk, Levy and Pinske, 2008). There is thus a clear need to better understand both the corporate motivations to engage in such reporting and the rhetoric the organisations use in these reports while pursuing particular ends (see e.g. Cho, 2009). Further, this research is motivated by the general ambiguity of the sustainability discourse. Businesses and frontgroups are keen to promote the so-called business view of sustainability as the way in which society should be developed (e.g. Holliday et al., 2002; Schmidheiny et al., 1992). This view, however, differs significantly from the sustainability advocated by certain other social actors (e.g. Gray, 2006). Springett (2003a) has emphasised that business front-groups have actively sought to mitigate the radical edge of sustainable development so that it would merely refer to the level of environmental and social commitment that corporations are comfortable with (see also Beder, 2002; Gray, 2002; Levy, 1997; Welford, 1997). Therefore, consonant with prior studies (Byrch et al., 2007; Spence, 2007; Tregidga and Milne, 2006) it is maintained here that analysing the business rhetoric of sustainability is important, since solving the urgent global and local environmental problems and progressing towards the ideal of sustainability is considered vital for humankind.

Accordingly, this study aims to answer the following research question: How did the corporate talk of sustainability as exemplified by the disclosures of three major Finnish companies develop in Finland during the period 1987-2005. In order to provide an indepth understanding of the development of the reporting this research focuses solely on the disclosures from four anchor points, namely (1) 1987, (2) 1992 and 1993, (3) 1999 and (4) 2005. The selection of these five years will be discussed in detail later in the paper. The corporate disclosures this study addresses include the annual reports and the stand-alone environmental, social, corporate responsibility and sustainability reports. It is argued that these reports are an active forum through which the discourse of business sustainability is further (re)constructed and (re)structured. The paper thus strives to contribute by showing how the business rhetoric of sustainability has transformed over time (see Buhr and Reiter, 2006; Livesey and Kearins, 2002; Milne, Kearins and Walton, 2006; Tregidga and Milne, 2006).

The paper is arranged as follows. First, the paper describes the discursive approach employed in the study. Second, the dataset is presented followed by the method of analysis. Third, a closer look is taken at the concept of sustainable development and on the discursive struggle around it. Fourth, the development of the disclosures of the three case companies is analysed. The penultimate section draws the observations together and discusses the findings. Finally, some concluding remarks are made. 


\section{THE APPROACH - DISCOURSES AND RHETORIC}

Following the 'linguistic turn' (Deetz, 2003; Rorty, 1967) the scientific community has been increasingly interested in the role of language in society. This study subscribes social constructionism (e.g. Berger and Luckmann, 1967; Gergen, 1999), according to which language does not simply reflect some underlying reality but, instead, has an active role in (re)constructing phenomena in social reality (Phillips and Hardy, 2002). Broadly, the approach employed here is part of the ambiguous family of discourse analytic methods (see Fairclough, 1992; Phillips and Hardy, 2002; Potter and Wetherall, 1987; Wetherall, 2001). In general, the study at hand addresses the role of language as a medium of (re)framing and (re)constructing concepts, phenomena and social practices in social reality. In particular, the focus is on the application of the concept of 'sustainable development' in the Finnish business context. This is deemed relevant, since the use of concepts, expressions and metaphors in society affects action, the way certain issues and phenomena are acted upon (see e.g. Dryzek, 1997). As will be shown later in this paper, sustainable development is somewhat contested territory. The different discourses in this discursive struggle also imply decidedly disparate modes of action in environmental and social issues.

Corporate disclosures are here considered as examples of corporate communication, for which organisations make strategic choices regarding rhetoric and rhetorical arguments (Vaara and Tienari, 2002). In Gergen's (1999: 42) view considering text as rhetoric means seeing language as "designed to do something within the community". The current paper does not concentrate on deconstructing the expressions from a rhetorical perspective (see e.g. Perelman, 1982). Instead, the focus is here on the broader spectrum looking at how the sustainability-related concepts are used and how the meanings of these concepts are (re)constructed in the disclosures. The terms rhetoric and corporate talk are here understood to subsume conscious choices of expression, metaphors, symbols and language, through which organisations aim at (re)framing and (re)presenting themselves in a particular light (see Craig and Amernic, 2004; Lawrence and Suddaby, 2006; Livesey, 2001; Suddaby and Greenwood, 2005).

The study aims at linking the developing corporate talk of sustainability with the broader discourses of sustainable development. The paper concentrates on analysing how the business talk of sustainability has developed on a meso-discursive level (Alvesson and Kärreman, 2000), exemplified in the disclosures of the three case companies. The discussion regarding the discursive struggle over sustainable development emanates from the existing literature. We concede that scrutiny of the discourses appearing in the Finnish context would be an asset to the study (see Alvesson and Kärreman, 2000: 1146). Such an analysis could, for instance, be conducted by researching how sustainability has been discussed and framed in the business media. However, the extensive amount of work involved in such an approach lies simply beyond the scope of this paper and, therefore, the limitations of the procedure applied are accepted. 


\section{DATA}

The dataset comprises selected disclosures of three major Finnish companies from a nineteen year period of 1987-2005. The companies represent different industries and can be considered to have been among the leaders of their respective sectors both businessand environmental-wise throughout the research period. The three case companies are Kesko, a leading company in the Finnish retail industry, Neste Oil, an energy company operating with a controversial non-renewable resource, and Stora Enso, a major player in the global pulp and paper business.

As will be described later on some mergers took place during the period and may well have played a part in the developments of the disclosures. Even though these restructurings pose challenges for the study, it should be noted that such changes are fairly common in the modern business world, and cannot be completely avoided in a longitudinal study (e.g. Buhr and Reiter, 2006). It could even be argued that trying to avoid such companies completely in the dataset would result in somewhat artificial case selection.

It would be complex to provide a profound and balanced analysis of all the disclosures by three companies over a nineteen-year period. Therefore, four anchor points, namely the years (1) 1987, (2) 1992 and 1993, (3) 1999 and (4) 2005, have been picked, and the case companies' disclosures are analysed in-depth from these five years only. Extended care was taken in choosing the anchor points. The year 1987 was selected as the starting point as those reports were the first after the publication of the Brundtland Report. The reports of 2005 were the latest available disclosures when this project started. In order to keep the total number of reports reasonable, only two interim points, 1993 and 1999, were chosen with a regular six-year interval between each anchor point. However, adhering to a strict structure in the data selection was considered inappropriate, since it has been pointed out (Laine, 2009) that swift transitions occur in the ways corporations use language in their social and environmental disclosures. The companies may, for instance, suddenly alter the main theme or the key concepts of the disclosures from one report to another. Therefore, the disclosures from the years initially selected through regular sixyear intervals were compared with those from the preceding and the following years from the perspective of sustainability. In the early 1990s swift changes do indeed take place in the case companies' disclosures: the extended discussion of sustainable development in Neste's disclosures in 1992 is totally absent in 1993, whereas in the reporting of Stora Enso's predecessor Enso the concept rises from being virtually non-existent in 1992 to centre-stage in 1993. Therefore, in the following analysis the anchor point in the early 1990s includes disclosures from two consecutive years, namely 1992 and 1993. It is maintained that such a purposive sampling (see Strauss and Corbin, 1990) helps in pursuing a rich description and an in-depth analysis of how the corporate talk of sustainability has developed in Finland. 


\section{METHOD AND ANALYSIS}

To recap, the dataset includes the annual reports and the stand-alone environmental, social, corporate social responsibility and sustainability reports published by three major Finnish companies at the aforementioned anchor points. A total of 15 annual reports and 7 other stand-alone reports were analysed. Finnish versions of the reports were used, since gathering a full dataset in English proved extremely difficult. All quotations presented in this paper were translated by the present author. [2]

The research included three full stages of analysis, which took place over a two and half year period. The first two stages were conducted by the researcher alone. However, in order to improve the reliability of the study a research assistant was invited to join the project for the third and final stage of analysis. [3]

The first stage of the analysis focused on a longer period of 1985-2005 and included all the disclosures of the three companies. It began with a read-through of all the reports and with a mark-up of all those passages containing any reference to social or environmental issues. The next round of reading focused on these sections and aimed to identify any use of sustainability-related concepts. These parts of the reports were collected into a database, the purpose of which was to aid in handling the otherwise unmanageably large bodies of text. The excerpts were organised and subsequently scrutinized both thematically and chronologically. The texts produced by each company were first analysed individually, after which these insights were drawn together and related with each other.

After an extended delay of 18 months the present author resumed the study. During this second stage of analysis all the disclosures from the same longer period of 1985-2005 and prior research journals were again read through and reinterpreted. The analysis included constant alternation between the database and the original reports, a process which ensured that the excerpts were analysed in their original context and, furthermore, allowed double-checking of the findings of the data collection phase. The extended break served to transform the dataset, which had seemed a veritable confusion, into a somewhat coherent story. It may well be that the extensive reading of other researchers' accounts of deconstructing corporate sustainability was essential in this respect.

Finally, the interpretations presented in this paper were formed in the third stage of analysis, undertaken independently by both the present author and the research assistant. At this stage the dataset was narrowed down to include only the disclosures from the anchor points of 1987, 1992 and 1993, 1999 and 2005. The research assistant was instructed to form her view of the reporting independently. She therefore had no access to the prior analysis conducted by the present author. The research assistant provided a written report of her views, and discussions were held on the interpretations. This process serves to reduce possible bias and subjectivity in the analysis, although we concede that removing them altogether lies beyond the scope of (all?) qualitative research. 
On the whole, the analytical method employed here is referred to as interpretive textual analysis, which explicitly emphasizes the subjective nature of the process. In developing the method the study has drawn on recent studies aiming at deconstructing business language with relatively similar interpretive methods (see Bebbington and Gray, 2006; Buhr and Reiter, 2006; Livesey 2001, 2002a, 2002b; Livesey and Kearins, 2002; Milne, Kearins and Walton, 2006; Milne, Tregidga and Walton, 2004; Tregidga and Milne, 2006). In practice, this study was conducted through numerous rounds of reading, followed by an interpretive analysis of the features and developments of the texts. The focus was on identifying patterns, exceptions, similarities and possible omissions both over time and between organisations. Throughout, answers were sought to questions such as "What is sustainable development?", "How is it defined?", "How is it achieved?", "Are there problems?", and "Why does the company bother with it?" The analysis progressed in a hermeneutical manner, applying no rigid framework as such.

The paper now moves on to briefly address the discursive struggle around sustainable development, before progressing to the discussion of the findings.

\section{BROADER DISCOURSES OF SUSTAINABLE DEVELOPMENT}

Even though some groups of public have been troubled by social and environmental issues for centuries (Buhr, 2007; Neuzil and Kovarik, 1996), the modern environmental awareness is often represented to have its roots in the 1960s (e.g. Elkington, 2004). The environmental problems caused by various social practices of the modern industrial and consumerist society have been given slowly increasing attention during the recent decades. One remarkable change in this discussion occurred in 1987, when the Brundtland Commission (UNWCED, 1987) introduced the concept of sustainable development. The term had been used earlier (Dixon and Fallon, 1989; Mebratu, 1998), but it was the Brundtland Commission's definition "development which meets the needs of the present without compromising the ability of future generations to meet their own needs" (UNWCED 1987: 8) that brought the concept to a broader social consciousness. Today, sustainability is not only a popular idea, but also a highly contested concept, over which consensus has only been achieved on the concept itself. There is a constant debate over what sustainable development actually means, how it could and should be achieved, and how urgently possible changes should be put into practice (e.g. Fergus and Rowney, 2005a, 2005b; also Gray, 2009).

The debate on sustainability has been described and conceptualized in various ways in the literature. For instance, Banerjee (2003) writes about discourses of sustainability without paying much attention to the differences between them, whereas Ratner (2004) focuses on the different conceptualizations of the discourse of sustainability. This study follows the work of Milne et al. (2006) and builds on a (simplistic?) dichotomy of two competing discourses, namely those of weak and strong sustainability. These ideal types are most often referred to with the aforementioned concepts, but various other terms are also used (see e.g. Adams, 1995; Pearce, 1993; Rossi et al., 2000; Shrivastava, 1994; Turner, 1993). 
The advocates of strong sustainability (e.g. Bebbington, 2001; Beder, 2002; Everett and Neu, 2000; Gray, 1992, 2002; Hildyard, 1993; Jacobs, 1991; Mayhew, 1997; Sachs, 1993; Springett, 2003a, 2003b; Welford, 1997) maintain that the prevailing social and economic order is a major culprit for the ever worsening environmental crisis afflicting humankind. The dominant economic system lives on economic growth, the continuity of which is considered impossible in strong sustainability (e.g. Daly and Cobb, 1989). Quite the contrary, further economic growth is seen to be making things even worse. In strong sustainability the issues of inter-generational and intra-generational equality are also deemed important (Bebbington, 2001; Dryzek, 1997). On the whole, the contemporary social and environmental problems are regarded as structural, and therefore radical solutions including a complete transformation of the status quo are called for (Gray, 2002; O'Connor, 1994; Everett and Neu, 2000).

An essentially different discursive approach is presented in weak sustainability. The most fundamental distinction from strong sustainability is in the perception of the prevailing social order. In weak sustainability it is maintained that social and environmental problems will be best solved by letting the market system foster technical innovations and solutions (e.g. Pearce and Barbier, 2000). Achieving sustainable development is seen to be contingent upon further economic growth, since without it society and social actors will not possess the resources required for innovating and developing further measures for environmental protection (see Adams, 1995; Dobson, 1995; Ekins, 1993; Meadowcroft, 2000). In contrast to strong sustainability, in weak sustainability nature and natural resources are considered to be of solely instrumental value for increasing human welfare (Shrivastava, 1995).

All in all, there is an evident on-going discursive struggle, in which business actors are also actively participating. Many commercial organisations, business front-groups and like-minded authors have brought forward the business view of sustainability, which is akin to weak sustainability (e.g. WBCSD, 2002). In general, the presentation of the business view often concentrates on win-win situations and case examples describing organisations which have succeeded in diminishing environmental impacts while simultaneously increasing profitability (e.g. Elkington, 1999; Holliday et al., 2002; Schimdheiny et al., 1992; also Rutherford, 2003). Critics have emphasized, however, that not all sustainability-related issues consist of win-win situations. Nevertheless, business front-groups and organisations are very powerful social actors and have succeeded in spreading the message of business sustainability throughout society. Thus, the social reality has been constructed in such a way that the status quo is currently often considered as the appropriate way forward and the critical minds are regarded, for instance, as opponents of modernity (see Banerjee, 2003). According to Springett (2003a) the protestations against further economic growth and other radical conceptions of sustainable development can be effectively silenced by owning the language of the debate. Therefore, this paper now takes a closer look at how Finnish business actors have de facto used the language of sustainability in their disclosures over time. 


\section{ANALYSIS OF THE CORPORATE DISCLOSURES}

This section presents the findings of the interpretive textual analysis. The disclosures of the companies were analysed one-by-one, which is also the way they are presented here. The text first provides an overview of the company, after which the disclosures from each anchor point are analysed in separate sections. In addition to the sustainability disclosures some other features of the reporting are described the better to familiarize the reader with the companies and the disclosures in question. The accounts of the development within the disclosures of individual organisations will then be drawn together in the next section.

\section{Kesko}

Kesko is one of the biggest providers of trading sector services in Finland. It was founded in 1941 and has been listed on the Helsinki Stock Exchange since 1960. Kesko is often considered one of the Finnish front-runners in environmental management and corporate responsibility. The company's environmental management programmes were started at the beginning of the 1990s. Kesko started publishing annual environmental reports in 1997, and has continued with corporate responsibility reports from 2000 onwards. Kesko has also received international recognition in this area, having, for instance, been included on a list of the Global 100 Most Sustainable Corporations in the World unveiled each year at the World Economic Forum in Davos (Corporate Knights, n.d.).

\section{7}

Kesko's annual report of 1987 contains 42 pages, approximately half being devoted to financial statements. In addition to the text and the financial figures the report contains some graphs, occasional illustrations and photographs of managers. All narratives are fairly short and concise, focusing on describing the past activities from an economic viewpoint. Some descriptive statistics concerning employees and training programmes are the only incidences of social and environmental issues in the annual report. Kesko's business idea is mentioned to include "responsible family-entrepreneurship", which is considered to be a "specific source of power" for the group (Kesko AR 1987: 2). However, the idea of responsibility is not yet used in building the company's identity to any further extent.

\section{2 and 1993}

No major changes take place in Kesko's reporting in the next five years. The 1992 and 1993 annual reports are about 60 pages long and the financial statements again fill about half of the documents. Some pictures are now used, even though in 1993 they feature solely the managers of different business units. The bulk of the narratives describes the company's operations sector by sector. The amount of copy has increased and the reports also include more general discussion on the company's operations. Even though the emphasis is still on the economic perspective, some environmental details are also given. 
From the perspective of this study the reports of 1992 and 1993 are fairly similar. The concept of sustainable development does not yet occur in Kesko's reporting. However, in both 1992 and 1993 the reports contain some details of the environmental initiatives, mainly concerning the packaging of products and the collecting and recycling of packaging materials. The rationale for this reportedly aims at "both taking care of environmental issues and diminishing the costs of business" (Kesko AR 1992: 37). Kesko had already started an environmental programme in 1990, but neither this nor any of the environmental initiatives figure prominently in these annual reports. There is now a separate section for environmental issues, albeit rather modest with a total length of five sentences in both 1992 and 1993.

1999

The volume of Kesko's voluntary disclosures increases swiftly during the 1990s. In addition to the 88-page annual report, Kesko also published a 40-page environmental report in 1999. Environmental and social issues are also frequently discussed in the annual report, which includes special sections for employees, environmental aspects, and ethical sourcing.

The main focus of Kesko's environmental disclosures is now on describing different kinds of environmental initiatives and on discussing future aims and challenges. In his statement the CEO describes how "we have continued to minimise our environmental impacts and started to evaluate our suppliers' production facilities from an ethical perspective" (Kesko AR 1999: 7). The rationale is made clear: Kesko wants to be the environmental leader in the trading sector. It is fairly evident from the disclosures that taking care of environmental issues is a means to an end, namely gaining competitive advantage. The environmental initiatives are represented as a way to influence consumers' activities, which from the company's viewpoint implies trying to increase sales. Likewise, "environmental issues were begun to be seen as a central dimension of business operations, through which the company can decrease costs and improve the quality of operations" (Kesko Environmental Report 1999: 5).

Although Kesko uses sustainability-related concepts seldom in 1999, its stance on sustainable development appears to follow the lines of weak sustainability. In parallel with a commitment to "advancing ecologically, socially and economically sustainable development in society" (Kesko AR 1999: 32), Kesko notes that "consumer optimism lays a strong foundation for growth" (Kesko AR 1999: 41). Combining sustainable development with increased sales of consumer goods may sound like an oxymoron to some, but according to the tenets of weak sustainability this is very much the name of the game. Accordingly, the company appears to claim that its activities are about promoting sustainable development. In its environmental report Kesko mentions that it has been included in the Dow Jones Sustainability Index. This is described as a "recognition for the work Kesko has done for sustainable development, environment and ethical issues" (Kesko Environmental Report 1999: 34). 
By 2005 Kesko had received numerous awards and constant acclamations regarding its activities in the field of corporate social responsibility. Likewise, its CSR reporting is considered to be amongst the best in Finland. In 2005 Kesko's annual report consisted of 128 pages, about a half of which was again devoted to the financial statements. The prestigious corporate responsibility report is a 72-paged document filled with detailed narrative enlivened with only a limited number of photographs.

At this stage Kesko's disclosures draw mainly on the discourse of corporate responsibility. Sustainable development and sustainability are only occasionally referred to in relation to some individual phenomena, as when linking ethical sourcing and socially sustainable development. For instance, Kesko repeatedly emphasises its inclusion in numerous sustainability indexes. However, it does not take a stand on what the concept of sustainability frequently mentioned in this context and in the names of these indexes is actually about. By leaving sustainability undefined Kesko actually suggests its own activities are indeed about sustainability.

The avoidance of sustainability-related concepts is interesting, because Kesko is an organisational stakeholder of the Global Reporting Initiative (GRI), and thus strongly committed to developing globally applicable sustainability reporting guidelines. Moreover, Kesko uses the GRI's sustainability reporting framework as the basis for its corporate responsibility report. Even though Kesko does not explicitly equate sustainable development with corporate social responsibility, these concepts appear to be used synonymously. In effect, in the GRI content index Kesko makes the connection: "vision of sustainable development" is listed to be discussed under the heading "vision of corporate responsibility" (Kesko AR 2005: 66).

All in all, sustainable development was not a core concept in Kesko's reporting during 1987-2005. It is likely that at least in the later anchor points this is due to a strategic choice, since Kesko's active participation in the GRI could be thought to have prompted the use of the sustainability-related concepts. Kesko's motivation for responsible business is fairly obvious: it aims, inter alia, at gaining a competitive advantage, at diminishing business risk, and at improving profitability. Furthermore, in Kesko's later disclosures sustainability seems to be more or less equivalent to responsibility. This further implies that one of the world's hundred most sustainable companies draws mainly on the discourse of weak sustainability in its disclosures.

\section{Neste Oil Corporation}

Neste Oil's roots are deep in the Finnish oil and energy businesses. Neste Oil's predecessor, the company Neste, was established in 1948. Neste was a fully state-owned company until it was listed on the Helsinki Stock Exchange in November 1995. In 1998 the State of Finland decided to merge two energy companies, Neste and IVO, in which it held a majority of the shares. Neste became a subsidiary of the new Fortum Group and began operations under the name of Fortum Oil. However, in early 2005 the oil 
businesses were separated from Fortum and listed on the Helsinki Stock Exchange as Neste Oil Corporation [for simplicity hereafter Neste].

Neste has long been active in environmental management. The company published its first annual environmental report in 1992. Neste subscribed to the Responsible Care initiative of the international chemicals industry at the beginning of the 1990s. Around the same time the company also made a strategic choice to concentrate on producing environmentally less harmful petroleum products. In addition, Neste has been included since 2007 in the list of Global 100 Most Sustainable Corporations in the World (Corporate Knights, n.d.). Even though the dataset ends before the company achieved inclusion in the list, its subsequent inclusion may still be considered indicative of its environmental reputation.

1987

Neste's 56-page annual report for 1987 is a glossy and colourful document for the time in question. Only about one third of the report contains financial statements, leaving considerable space for narrative and graphs. The report includes an environmental section one page long, in addition to which environmental issues are also mentioned a number of times in other parts of the text.

The term sustainable development does not yet appear in Neste's disclosures. Otherwise, however, the company discusses environmental issues from various viewpoints and describes intense discussions on environmental protection in the company. The company indicates that it "acknowledges the implications its activities have on the environment, and the interest the public has in the measures the company takes for environmental protection" (Neste AR 1987: 48). Furthermore, Neste notes that its environmental policy is "aiming actively and openly at harmony with the environment" (Neste AR 1987: 48). Anticipating the company's future development it also underscores that from its viewpoint "environmental protection is transforming from a burden to a possibility" (Neste AR 1987, 5).

\section{2 and 1993}

Neste published its first environmental report of 38 pages in 1992 and expanded it to 52 pages the following year. In addition, the company also addresses environmental issues in the annual reports of both 1992 and 1993. At a glance these disclosures seem relatively similar: in both years the disclosures include discussion on the importance of overall social acceptability, on the occasional failures in Neste's environmental management, and on the imperatives the environmental agenda sets for corporate management more broadly. There is, however, a remarkable difference in how the sustainability-related concepts are used, as in 1993 the company did not use these terms at all.

In general, Neste's disclosures in the early 1990s could be characterized as problemoriented. Instead of subscribing exclusively to the usual business rhetoric of good 
environmental management the company also describes the possible negative implications of increasing environmental awareness in society for its operations:

"Sustainable development entails conserving the natural resources, producing less waste and utilizing more of it, and minimizing the environmental harm. The chemicals industry and most of the Neste's products are in the line of fire." (Neste and the Environment 1992: 11.)

Neste emphasises the amount of power society and the public have over corporations. A recurring theme in the disclosures at this point in time dwells on how the company is simply compelled to do certain issues. According to Neste's disclosures no company can operate in society without the approval of society at large. In essence, Neste is maintaining that social legitimacy is indispensable for the company. Furthermore, the societal demands appear to stem from the idea of sustainable development:

"In the 1990s our society will not accept 'free riders'. The management of the company has to more and more take into account the limits of resources and nature's carrying capacity." (Neste and the Environment 1992: 3.)

"In the future success will depend increasingly on whether society accepts the environmental impacts and risks caused by production and products, and whether the production is environmentally sustainable." (Neste AR 1992: 47).

However, despite the problem-orientation Neste also shows signs of confidence and claims that its active approach to environmental issues will lead to further success. The company's CEO maintains that "environmental protection and profitability affect one another both today and on the way towards sustainable development" (Neste and the Environment 1992: 3). As in 1987 Neste argues that it will gain competitive advantage from environmentally friendly products.

On the whole, the disclosures create a somewhat anomalous picture of the company's position. Neste provides positive accounts of the compatibility of the current measures in environmental protection, profitability and sustainable development. However, it simultaneously also admits the magnitude of the sustainability agenda and the industry's problematic position concerning it. Neste seems to have been uncertain as to how sustainable development should be interpreted and how it is to reach this new target.

1999

Neste became a subsidiary of Fortum in 1998. In 1999 Fortum published its first social and environmental report, the 32-page "Fortum in Society". The rhetoric in the disclosures has changed remarkably from the previous anchor years: emphasis is now given to opportunities and other positive expressions. The merger may well have played an important part in this transition. However, the data does not facilitate an analysis of the reasons underlying this change. 
Sustainable development is given a major role in the disclosures of 1999. This is especially the case with the CEO's statement in the stand-alone report entitled "Towards sustainable development" (Fortum in Society 1999: 2). The statement begins with a short description of the company's strengths, including skilled personnel and high-quality production facilities. The greatest challenges are described to include the "company's dependence on fossil fuels and the general acceptability of nuclear power" (ibid). Thus, fossil fuels, including oil, are still somewhat problematic but by no means an obstacle for sustainable development:

"Can an energy company, whose product range includes all forms of power production, from solar and wind to oil, coal and nuclear, even talk about sustainable development? I believe it can, and it must." (Fortum in Society 1999:

2.)

More broadly, Fortum is described as a pioneer, in which "change has already begun" (Fortum in Society 1999: 2). The company's new operating principles include a commitment of "reconciliation of the dimensions of sustainable development, namely economic, environmental protection and social responsibility" (ibid). This is claimed to entail more than just taking care of the traditional duties of environmental protection, but being a "corporate citizen" (ibid).

The general mood of the disclosures is positive. Fortum is described as an environmentally friendly and eco-efficient company whose competitive advantage derives from its progressiveness in environmental issues. The problematic nature of fossil fuels is partially dispelled by talking of long-term strategic goals, such as improving of energy efficiency and increasing the share of renewable and low-carbon natural resources in the production. Advancing towards sustainable development appears not to necessitate any major changes in the way the company is operating, despite the caveat given by the CEO concerning the complexity of this task: "I hope this report conveys our true will to advance on the difficult road towards sustainable development" (Fortum in Society 1999: 2 ). Likewise, the unproblematic representation of sustainability slightly contradicts the occasional portrayals of the magnitude of the idea:

"Sustainable development is a huge challenge for the whole globe. - - New kind of thinking is required, also in companies, concerning the needs of the future and on our own role as creators of social wellbeing." (Fortum in Society 1999: 2.)

Nevertheless, in Fortum's disclosures in 1999 sustainable development is used mainly as a general term with only a vague content. Sustainability requires a new way of thinking and a reconciliation of various dimensions in the decision-making. Here, however, the new way is represented to include mainly incremental improvements in current operating practices. 
Neste's merger with Fortum did not work out as planned and in 2005 Neste was again an independent listed company. The company's approach to voluntary disclosures, however, changed. Whereas in the pre-Fortum era Neste published highly esteemed environmental reports, it now integrated social and environmental reporting into its annual report. In this process the volume of these disclosures also decreased: there are some ten pages of social and environmental information in the 124-paged annual report. The company seems to build on its previous reputation as an excellent environmental reporter:

"Neste Oil has been a forerunner in environmental and corporate citizenship reporting. The former Neste Corporation is the only Finnish company to have won the European Environmental Reporting Award for its Corporate Health, Safety and Environmental Report, in 1999." (Neste AR 2005: 31.)

Nevertheless, Neste's reporting in 2005 is rather modest. The company is described as a pioneer, which focuses on cleaner fuels and environmentally friendly products. Responsibility features as a central concept in Neste's disclosures and appears to entail mainly risk management and economic responsibility. For instance, numerous environmental initiatives are justified by cost savings and other financial aspects. Furthermore, from the sustainability perspective it is noteworthy that sustainability is equated with corporate responsibility:

"A responsible approach to business is simply a way to achieve the goals of the business. At the same time it is in accordance with company's values: it is important to operate in a sustainable way." (Neste Oil AR 2005: 30.) [4]

In general, a change has taken place in the use of the sustainability-related concepts. Both in 1992 and 1993 and in 1999 sustainable development was discussed from various perspectives. The use of fossil fuels has been described as problematic and the general challenges have been admitted to be huge. In 2005, however, no such depiction is made. It seems that there is no longer any need to explain why sustainable development should be an aim for business. Instead, sustainability simply gets done. As it is defined in the Neste's company goals:

"Act responsibly in society and in the use of natural resources, and make decisions supportive of sustainable development."(Neste AR 2005: 31.)

All in all, major changes have occurred in the way Neste has used the sustainabilityrelated concepts in its disclosures over the nineteen-year period. In the early 1990s sustainability featured as a fairly strong phenomenon, which was about to bring along radical changes to the business reality of a company dependent on non-renewable oil resources. However, after just over ten years the concept has become diluted to mean little more than the usual business responsibility. For example, back in the early 1990s the disclosures suggest that the use of oil will not be acceptable in the new era of sustainable development. However, in 2005 manufacturing environmentally less harmful 
oil products seems to be fully compatible with sustainable development. The use of nonrenewable resources is no longer a problem but, rather, a social imperative. There are at least two possible explanations for this change: Firstly, the concept could have been intentionally tamed, implying yet another example of how business has captured the concept of sustainability (see Welford, 1997). Secondly, the change may be due to a sincere belief that the company's activities have so far been highly successful and that the company is on the right track towards sustainability with its "cleaner traffic fuels". Further analysis lies beyond the scope of this paper, but studies like Cho (2009) combining disclosure analysis with interview data could provide interesting insights on management's views of disclosure choices in such cases and are therefore highly recommended.

\section{Stora Enso}

The pulp and paper company Stora Enso was formed in a merger between Finnish Enso and Swedish Stora in 1998. As the study at hand focuses on the developments in the Finnish business community, the dataset contains the pre-merger disclosures of Enso and its predecessor Enso-Gutzeit [for simplicity hereafter Enso] in addition to the more recent Stora Enso reports.

Stora Enso is a global market leader in many of the products it produces. The company's environmental performance has also been highly appreciated. For example, Stora Enso is the only forest sector company to appear in the Dow Jones Sustainability Index every year since the index was founded in 1999. Moreover, like Kesko and Neste, Stora Enso has also once been included in the list of Global 100 Most Sustainable Corporations in the World (Corporate Knights, n.d.). Furthermore, the company's predecessors Enso and Stora had been active in environmental issues. In Finland, Enso had signed the ICC business charter for sustainable development in 1991 and published an environmental report on an annual basis since 1994.

\section{7}

In 1987 Enso's 60-page annual report is rather traditional, with financial statements taking nearly half of the pages and the narratives accompanied by some graphs and pictures of managers and products. So far there is no discussion of sustainable development. The annual report includes, however, a separate environmental section, which at two pages is an extended example for the time in question. Environmental protection does not appear to be an integral part of the production, but is positioned as something external: "Capital has not been spent on production only. Capital expenditure on environmental protection, for example, was three times higher than the year before." (Enso Gutzeit AR 1987: 4.) The drivers of environmental protection are described to be external pressures like international agreements and strict national legislation. The company's efforts in environmental protection are deemed to be highly successful and appear to comprise mainly technical end-of-pipe solutions. 
Even though Enso did not yet publish a stand-alone environmental report, environmental issues feature in a major role in the disclosures in the early 1990s. In 1992 environmental issues are discussed frequently throughout the annual report. Emphasis is given to reductions in emissions and to the development of new products, especially from recycled fibres. The environmental initiatives are driven by external pressures: Enso maintains that, in addition to the authorities, the public and especially the customers also now have expectations of the company. The environmental aspects appear to have had a great significance for the company at the time. It maintains, for instance, that "only those manufacturers whose products are accepted on environmental grounds by customers will survive this period of transition" (Enso Gutzeit AR 1992: 44).

However, sustainable development is not brought to the forefront until 1993. In 1992 Enso uses the concept only once: "Enso pays particular attention to predicting the environmental impacts of its operations to ensure that business is kept on a sustainable basis in this respect" (Enso Gutzeit AR 1992: 10). By contrast, in the annual report of 1993 sustainable development is a prominent concept. There are altogether approximately ten full pages of narrative in the 52-page annual report. Of those a special section titled "Enso believes in sustainable development" (Enso Gutzeit AR 1993: 42) takes up two, being the only theme discussed in addition to the business sector reports.

In Enso's reporting in 1993 sustainable development is a purely environmental concept, albeit a fairly strong one. The first paragraph of the section discussing Enso's position on sustainable development includes the following:

"The ecology movement is no passing fashion. It is a total and permanent change that is affecting our Western way of life, a change that no company can afford to ignore when planning its future." (Enso Gutzeit AR 1993: 42).

Enso is nevertheless self-confident regarding sustainable development. The company wants to draw a clear distinction between the preceding decades of economic growth, when "along with other sectors of society the industry was guilty of an easy-going attitude that idolized efficiency" (Enso Gutzeit AR 1993: 42) and the new Enso, which has developed "new approaches that stress the ecological standpoint" (ibid). Even though the company admits that "self-criticism is not a bad thing" (ibid), it is keen to emphasise that when it comes to sustainable development the forest industry is better than its reputation. The company feels it does not deserve "the kind of scathing criticism" (ibid) it has received, especially from abroad:

"Many assessments of the state of Finland's forests have been founded on a complete lack of understanding of the conditions that prevail here. In this sense, the picture of ecological sustainability as it relates to Finland's forests needs some clarification." (Enso Gutzeit AR 1993: 43.) 
"Sustainable development is nowhere more applicable than in the forest industry, as the industry's entire existence depends on it." (Enso Gutzeit AR 1993: 42.)

Sustainable development is represented as a broad concept, but Enso elaborates relatively little on its actual content. The company does mention that "ecologically sustainable development and the preservation of biodiversity have assumed the dimensions of principles, to which countries have committed themselves in international forums" (Enso Gutzeit AR 1993: 42). Some details on what sustainable development actually entails are also given, like using renewable resources, cutting emission levels, treating waste waters, and recycling end products. Furthermore, it appears that sustainable development is not only a technical issue, but also a matter of communication. Enso claims it has been successful on both fronts:

"During the 1990s, environmental considerations have become an essential requirement for the success of forest products companies. In addition to the right price, high quality and reliable deliveries, producers have to be able to convince all parties concerned that they are operating on an ecologically sustainable basis. Enso is strongly committed to meeting this challenge, and has already achieved notable results." (Enso Gutzeit AR 1993: 7.)

1999

Finnish Enso and Swedish Stora merged in 1998 and formed Stora Enso. In 1999 social and environmental issues are given separate sections in the Stora Enso's 100-page annual report, in addition to which the company published a 36-page stand-alone environmental report.

Sustainable development continues to occupy an important position in Stora Enso's disclosures. However, the general approach to sustainability has changed by 1999. Even though the company occasionally mentions the principles of sustainable development, like in its environmental policy, the use of this formerly popular conceptualization is declining. Instead, the main point is now advancing towards ecological, social and economic sustainability. Thus, the quest for sustainable development transforms from following certain principles into a journey towards an ideal, yet unknown, destination (see e.g. Milne et al., 2006). Simultaneously, the earlier emphasis on environmental issues is modified into the three-pillar representation of sustainability, which has for some time been perhaps the dominant representation of it in the business-oriented sustainability literature (e.g. Elkington, 1999).

Renewable resources are now used more extensively than before in the sustainability rhetoric. Stora Enso often accentuates how its raw material supply is linked to sustainable forest management, sustainable forestry, sustainable methods, sustainable fibre sources and sustainable plantations, to name but a few. The company utilises the renewability of forests as a rhetorical device to prove the sustainability of the company as a whole. However, the constant repetition risks reducing the concept to a buzzword, with no clear meaning. Indeed, sustainability is used as an umbrella term: "[sustainability] requires a 
holistic grasp of a wide range of economic, ecological and social issues" (Stora Enso Environmental Report 1999: 5). Moreover, the blurry relationship between corporate responsibility and sustainability further increases the fuzziness:

"Environmental responsibility means that we comply with the principles of sustainable development in all our operations.” (Stora Enso AR 1999: 5.)

"Responsible business: Stora Enso is committed to developing its business towards ecological, social and economic sustainability." (Stora Enso Environmental Report 1999: 8.)

Despite the agenda's multi-dimensionality, Stora Enso's efforts appear to be successful in this respect, since the disclosures feature mainly positive aspects and the company is able to maintain that "sustainability is embedded in the business" (Stora Enso AR 1999: 37). The rationale for embracing sustainability is clear: Stora Enso wants to become the world's leading forest products company. Becoming a global leader in various paper products requires focusing on sustainable development, since "the top companies count on sustainability” (Stora Enso Environmental Report 1999: 5). All in all, sustainable development is depicted as a pervasive value, which will raise the company's (financial) performance to a higher level.

2005

In 2005 Stora Enso's disclosures include three reports, one of which is titled "Sustainability". This comprehensive 54-page report includes impressive amounts of detail and discusses Stora Enso's operations, aspirations and performance from various perspectives.

Stora Enso openly admits that sustainability issues are very complex. The disclosures are nevertheless filled with the usual contemporary business rhetoric of balancing the economic, social and environmental aspects of sustainability. However, when facing financial hardship the eternal win-win ethos disappears and the company concedes the juxtaposition of profitability and sustainability, albeit with attempts to downplay the contradictions:

"At Stora Enso we believe that long-term financial success is the key element of sustainability for business. Excellent social and environmental performance will not prolong the life of a company that is economically unsustainable." (Stora Enso Sustainability Report 2005: 4, 36.)

"But even in this currently difficult [financial] situation, Stora Enso will not compromise on the Group's ambitious sustainability objectives.” (Stora Enso Sustainability Report 2005: 2.) [5]

In contrast to the earlier years, when sustainability appeared as a society-wide concept, in 2005 Stora Enso's disclosures represent it predominantly as an internal issue, namely 
business sustainability. Apart from climate change, no external social or environmental phenomena are mentioned as drivers of sustainability. Wider social and environmental problems appear to exist only in the sections devoted to philanthropy and strategic partnerships with the likes of UNDP and WWF. It is underscored right from the outset of the disclosures that sustainability is no longer an objective as such but, rather, only a means to an end, namely further growth and value creation for the shareholders. The key message is given in the opening words: "Sustainability supports profitability" (Stora Enso Sustainability Report 2005: 4).

Another interesting feature of Stora Enso's reporting at this point in time is the relationship between sustainability and responsibility. In 2005 the company defines sustainability as "an umbrella term to describe responsible business operations that include economic, environmental and social responsibility” (Stora Enso Sustainability Report 2005: 6). Sustainability is represented to entail reducing risks, fulfilling accountability and taking optimal care of economic, social and environmental issues. Using sustainability in this sense dilutes the concept to mean no more than the usual corporate responsibility and the company might equally well have used the concept of responsibility throughout the report. Apparently Stora Enso considers sustainability a term with higher social value. Or perhaps it is about subscribing to the wider social myth of sustainability (see Spence, 2007), which will solve the environmental problems and social injustice without forcing the business community or the consumerist culture to give up anything from the status quo.

\section{DISCUSSION OF THE FINDINGS}

This study analysed how the corporate talk of sustainability developed in Finland in the period 1987-2005. Before discussing the findings in the broader context the limitations of the study will be addressed. The purposive sampling and the use of anchor points are not without problems. Some details were inevitably lost, since the corporate disclosures from all the nineteen years of the period were not analysed. However, it is maintained that the possible drawbacks are outweighed by the in-depth insights facilitated by the more concise dataset. Furthermore, the initial analysis conducted including all the disclosures from the period increases the reliability of the representation given here. The intrinsic subjectivity of the interpretive approach was addressed by having a research assistant as the second coder, although it is acknowledged that the possible biases caused by the personal position of the researcher cannot be removed completely. Finally, the study focuses on only three case companies in one particular country, and thus the generalisation of the findings should be approached with caution. Despite these limitations, it is maintained that the study contributes to the discussion on how corporations have used the language of sustainability in their disclosures.

It is obvious that even though the companies earlier used and appeared to conceptualize sustainable development in rather distinct ways, the polyphony fades away over time and the rhetoric becomes increasingly similar. In 1987, the year the Brundtland Commission

published Our Common Future, sustainable development does not yet occur in the 
disclosures of these particular companies. In the early 1990s, however, sustainable development became a major concept for describing the relationships between business, society and nature. The impetus is likely due to the launch of the ICC Business Charter for Sustainable Development in 1991, and the UNCED summit in Rio de Janeiro in 1992. At that time sustainable development appears as a strong phenomenon represented by the case companies as incompatible with the prevailing business practices with comments such as "we and our products are in the line of fire" (Neste Oil AR 1992: 11) or as ecology bringing "total change" (Enso Gutzeit AR 1993: 42) to western ways of living and doing business. Such a strong tone later fades away, to some extent already in 1999 and completely by the last anchor point of 2005, when the companies represent current business activities as compatible with sustainable development. There is talk about "journeying towards sustainable development", "balancing social, economic and environmental dimensions" and "operating in a sustainable way" (see Milne et al., 2006; also Laine, 2005). However, in a certain sense such balancing is compromised with the explicit underscoring of the priority of economic success as the precondition for taking care of environmental and social responsibilities. Sustainable development is nevertheless portrayed as a feasible objective, something which is either already embedded into everything the company does, or is at least achievable. Even though it is fairly obvious that the relative environmental impacts of these companies have diminished through, for instance, increased eco-efficiency, it is implausible to profess that the interlinked social and environmental problems related to sustainable development have been solved in such a short time (see Gray, 2006). Rather, the matter is more about a change in the way the companies aim to represent their relationship with environmental and social issues. This also suggests that it is worth paying attention to how corporations use language in their carbon disclosures, an area of growing significance (see Bebbington and LarrinagaGonzález, 2008; Kolk et al., 2008).

Spence (2007) maintains that there has been a change in how business in general seems to understand sustainable development. Referring to Bebbington and Thomson (1996) Spence (2007: 875) argues that "business conceptions of sustainable development in the 1990s contained a greater acceptance of conflicts between business and society" than was found in his more recent study. According to Spence the agenda of sustainable development came originally as something of a surprise to business, causing business actors trouble in understanding and reflecting on it. Spence (2007: 875) further refers to papers by Milne et al. (2006) and Tregidga and Milne (2006) and argues that "business manages now to talk confidently about sustainable development and its ability to deal with it." The study at hand shows that similar developments have taken place in the disclosures of major Finnish companies. In the early 1990s the talk of sustainability appearing in the disclosures acknowledges the inherent conflicts in the relationships between business, society and nature. There is an evident dichotomy between the different views of sustainability, exemplified by Enso's proclamation of their "belief" in sustainable development. The representation was, however, mixed: even though the change is described as major, the solutions are by no means revolutionary. Operations are described to be continuing as before, only better. Furthermore, in 1993 and to a large extent also in 1999 the drivers of sustainability are described as external, stemming from broader social issues. By contrast, in 2005 conflicts between business, society and nature 
are downplayed and the focus is on how business provides sustainable solutions. The external drivers have disappeared and the sustainability agenda is based on the companies' free will. To some extent the content of sustainability now appears to be taken for granted. Sustainability has become a common way of doing business, embedded in everyday operations. It is simply "important to act in a sustainable way" (Neste AR 2005: 30). Thus, sustainability just gets done.

Byrch et al. (2007) note major differences in how "different camps" conceptualize sustainable development in New Zealand. In their view it comes as no surprise that the identified business camp draws on a very weak version of sustainability. They further maintain that sustainable development has not progressed in the country and call for further studies exploring how business uses concepts such as sustainable development for its own ends. On the same subject, Banerjee (2003: 163) argues that "discourses of sustainability are becoming increasingly corporatized" and remains critical of discourse shifting from concepts of sustainable development and sustainability to corporate sustainability, which "produce an elision that displaces the focus from global planetary sustainability to sustaining the corporation through "growth opportunities"'. Banerjee maintains that the corporate discourse of sustainable development implies no radical changes in world views and promotes the continuum of existing social institutions and business as usual. Accordingly, a pronounced feature in the latest disclosures analysed here is how sustainability is assimilated with corporate social responsibility. This is apparent in the disclosures of all three companies and coincides with the disappearance of the external social imperatives. Sustainability is demoted into a concept consisting of taking proper care of social, economic and environmental issues. However, instead of the social level the focus is on the corporate perspective. Thus, the main goal in embracing sustainability (i.e. responsibility) is to improve corporate profitability (see also Hopwood, 2009: 438).

The findings on how the business rhetoric of sustainability has transformed in the Finnish corporate disclosures suggest that it is worth exploring whether the business interpretation of sustainability is about to assume a hegemonic position. Such a conclusion is far beyond the scope of this study, but the findings' discernible resemblance to prior research (Banerjee, 2003; Buhr and Reiter, 2006; Byrch et al., 2007; Milne et al., 2006; Spence, 2007; Tregidga and Milne, 2006) warrants pondering on such a scenario and calls for further studies on how the business discourse of sustainable development is developing more generally in society. According to Fairclough (2003: 58; also Laclau and Mouffe, 2001/1985) "seeking hegemony is a matter of seeking to universalize particular meanings in the service of maintaining or achieving dominance". If the business conceptualization of sustainability gains hegemony over the other interpretations, important social and environmental issues will become increasingly peripheral (see Byrch et al., 2007). Furthermore, since the way concepts and phenomena are talked about affect action (Dryzek, 1997), it is here maintained that deconstructing such a hegemony is important (see Spence, 2007). 


\section{CONCLUDING REMARKS}

In recent years sustainable development has effectively been mainstreamed and the sustainability-related concepts have become more commonplace than ever before. However, it appears somewhat paradoxical that even in the midst of the burgeoning sustainability a number of indicators show that the state of the global environment continues to deteriorate (e.g. Bebbington and Larrinaga-González, 2008; Gray, 2006).

It has been argued (e.g. Beder, 2002; Gray, 2006) that over the years sustainability has lost its radical edge (if it ever had one). Accordingly, this study shows that the way three leading Finnish companies talk about sustainability in their disclosures has changed significantly in less than two decades. The possibly substantial initiative has dwindled into a silent evolution, if not to merely sustaining of the status quo. The disclosures permit no conclusions as to whether this is the outcome of a deliberate move or is due to other reasons. Be this as it may, the findings suggest that Finnish business has succeeded in integrating sustainability into the business rhetoric.

In retrospect, it seems relatively clear that the business talk has become closely associated with the ideals of weak sustainability. It might thus be worth exploring further the business rhetoric of sustainability appearing in other forums, such as the business media. In addition, it would be essential to ascertain how the key figures in leading companies and in the national business sustainability front-groups conceptualize sustainability. This is because the discourse of weak sustainability shows signs of becoming hegemonic (see Fairclough, 2003), and as such a taken for granted meaning dominating competing conceptions of sustainable development. Such a situation is argued to be problematic (see Spence, 2007; also Byrch et al., 2007), since the business discourse of sustainability appears to be more about sustaining businesses and capitalism (Banerjee, 2003) at the expense of nature. Thus, it is debatable whether the increasing emphasis on sustainability is actually propelling society in that direction.

\section{Notes}

[1]: For the sake of simplicity the concepts of sustainable development and sustainability are here used largely interchangeably, even though one could perhaps see a problem in the indiscriminate use of sustainability-related concepts in a paper focusing on how the very same concepts are used in corporate disclosures.

[2]: The Finnish versions have been the primary source and the analysis presented in this paper is based on them. In providing the quotations the English versions of the reports have been consulted if they have been available. However, the quotations have been taken directly from the English versions only if the author had assessed the meaning to be similar in both versions. In other cases the quotations have been taken from the Finnish version and have been translated by the author in order to remain consistent with the analysis. See also footnote 4 .

[3]: At the time the research assistant was a PhD student in accounting with a special interest in human relations and social accounting.

[4]: In this quotation there is a clear difference in the emphasis of the Finnish and English versions. The English version of the annual report reads as follows: "A responsible 
approach to business not only contributes to achieving business objectives, it also reflects a company's commitment to operating in accordance with its values and sustainably." (Neste AR 2005 English Version: 30). Furthermore, the company appears to use the terms "responsibility" and "sustainability" interchangeably: a subtitle which reads "On responsibility reporting" in the Finnish version has transformed to "Sustainability reporting" in the otherwise equivalent English version (Neste AR 2005 Finnish Version: 30; Author's translation; Neste AR 2005 English version: 30). The Finnish version is used here in order to be consistent with the other years. However, on a more general level it might be worth studying how much the different versions of annual reports portrayed to be identical actually vary in terms of language use (see Campbell, Beck and Shrives, 2005).

[5]: A cynic might ask whether the environmental objectives really are so ambitious, as many of those reported to be targets in five years' time in 2009 appear already to have been achieved during 2005, the first year of the period.

\section{References}

Adams, W.M. (1995) Green development theory: Environmentalism and sustainable development, in Crush J. (ed.) Power of Development. (London: Routledge).

Alvesson, M. and Kärreman, D. (2000) Varieties of discourse: on the study of organisations through discourse analysis, Human Relations, 53(9), pp. 1125-1149.

Banerjee, S.B. (2003) Who sustains whose development? Sustainable development and the reinvention of nature, Organisation Studies, 24(1), pp. 143-180.

Bebbington, J. (2001) Sustainable development: a review of the international development, business and accounting literature, Accounting Forum, 25(2), pp. 128157.

Bebbington, J. and Gray, R. (2006) A social constructionist analysis of sustainable development in United Kingdom environmental reports, paper presented at the $8^{\text {th }}$ IPA Conference in Cardiff, July 2006.

Bebbington, J. and Larrinaga-González, C. (2008) Carbon trading: Accounting and reporting issues, European Accounting Review, 17(4), pp. 697-717.

Bebbington, J. and Thomson, I. (1996) Business Conceptions of Sustainability and the Implications for Accountancy, ACCA Research Report no. 48. (London: ACCA).

Beder, S. (2002) Global Spin - The Corporate Assault on Environmentalism, revised edition. (Devon: Green Books).

Berger, P. and Luckmann, T. (1967) The Social Construction of Reality: A Treatise in the Sociology of Knowledge. (Harmondsworth: Penguin).

Buhr, N. (2007) Histories of and rationales for sustainability reporting, in Unerman, J., Bebbington, J. and O'Dwyer, B. (eds.) Sustainability Accounting and Accountability. (London: Routledge).

Buhr, N. and Reiter, S. (2006) Ideology, the environment and one worldview: A discourse analysis of Noranda's environmental and sustainable development reports, Advances in Environmental Accounting and Management, 3, pp. 1-48. 
Byrch, C., Kearins, K., Milne, M. and Morgan, R. (2007) Sustainable 'what'? A cognitive approach to understanding sustainable development, Qualitative Research in Accounting and Management, 4(1), pp. 26-52.

Campbell, D., Beck, C. and Shrives, P. (2005) A note on comparative language interrogation for content analysis: The example of English vs German, British Accounting Review, 37(3), pp. 339-350.

Cho, C.H. (2009) Legitimation strategies used in response to environmental disaster: A French case study of Total SA's Erika and AZF incidents, European Accounting Review, 18(1), pp. 33-62.

Corporate Knights (n.d.) Global 100: Most sustainable corporations of the world. Available at <http://www.global100.org/index.asp>. Accessed 9.6.2008.

Craig, R. and Amernic, J. (2004) The deployment of accounting-related rhetoric in the prelude to a privatization, Accounting, Auditing and Accountability Journal, 17(1), pp. 41-58.

Daly, H.E. and Cobb, J.B. (1989) For the Common Good. (Boston: Beacon).

Deetz, S. (2003) Reclaiming the legacy of the linguistic turn, Organisation, 10(3), pp. 421-429.

Dixon, J.A. and Fallon, L.A. (1989) The concept of sustainability: Origins, extensions and usefulness for policy, Society and Natural Resources 2, pp. 73-84.

Dobson, A. (1995) Green Political Thought. Second edition. (London: Routledge).

Dryzek, J.S. (1997) The Politics of the Earth: Environmental Discourses. (New York: Oxford UP).

Ekins, P. (1993) Making development sustainable, in Sachs, W. (ed.) Global Ecology: A New Arena of Political Conflict. (London: Zed Books).

Elkington, J. (1999) Cannibals with Forks. The Triple Bottom Line of $21^{\text {st }}$ Century Business. (Oxford: Capstone).

Everett, J. and Neu, D. (2000) Ecological modernization and the limits of environmental accounting? Accounting Forum 24(1), pp. 5-29.

Fairclough, N. (1992) Discourse and Social Change. (Cambridge: Polity Press).

Fairclough, N. (2003) Analysing Discourse: Textual Analysis for Social Research. (London: Routledge).

Fergus, A.H.T. and Rowney, J.I.A. (2005a) Sustainable development: Epistemological frameworks and an ethic of choice, Journal of Business Ethics, 57, pp. 197-207.

Fergus, A.H.T. and Rowney, J.I.A. (2005b) Sustainable development: Lost meaning and opportunity, Journal of Business Ethics, 60, pp. 17-27.

Gergen, K.J. (1999) An Invitation to Social Construction. (London: Sage).

Gray, R. (1992) Accounting and environmentalism: An exploration of the challenge of gently accounting for accountability, transparency and sustainability, Accounting, Organisations and Society 17(5), pp. 399-425.

Gray, R. (2002) Of messiness, systems and sustainability: Towards a more social and environmental finance and accounting, British Accounting Review 34, pp. 357-386.

Gray, R. (2006) Social, environmental and sustainability reporting and organisational value creation? Whose value? Whose Creation? Accounting, Auditing and Accountability Journal, 19(6), pp. 793-819. 
Gray, R. (2009) Is accounting of sustainability actually accounting for sustainability...and how would we know? An exploration of narratives of organisations and the planet. Accounting, Organizations and Society, doi: 10.1016/j.aos.2009.04.006.

Hildyard, N. (1993) Foxes in charge of chickens, in Sachs, W. (ed.) Global Ecology: A New Arena of Political Conflict, pp. 22-35. (London: Zed Books).

Hines, R.D. (1988) Financial accounting: In communicating reality, we construct reality, Accounting, Organisations and Society, 13(3), pp. 251-261.

Holliday, C.O.jr., Schimdheiny, S. and Watts, P. (2002) Walking the Talk, The Business Case for Sustainable Development. (Sheffield: Greenleaf).

Hopwood, A.G. (2009) Accounting and the environment, Accounting, Organizations and Society, 34 (3-4), pp. 433-439.

Jacobs, M. (1991) The Green Economy: Environment, Sustainable Development and the Politics of the Future. (London: Pluto Press).

Kolk, A., Levy, D. and Pinske, J. (2008) Corporate responses in an emerging climate regime: The Institutionalization and Commensuration of Carbon Disclosure, European Accounting Review, 17(4), pp. 719-745.

KPMG (2008) KPMG International survey of corporate responsibility reporting 2008. (Amsterdam: KPMG International).

Laclau, E. and Mouffe, C. (2001/1985) Hegemony and Socialist Strategy: Towards a Radical Democratic Politics, second edition. (London: Verso).

Laine, M. (2009) Ensuring legitimacy through rhetorical changes? A longitudinal interpretation of the environmental disclosures of a leading Finnish chemical company. Accounting, Auditing and Accountability Journal, 22(7), pp. 1029-1054.

Laine, M. (2005) Meanings of the term 'sustainable development' in Finnish corporate disclosures, Accounting Forum, 29, pp. 395-413.

Lawrence, T.B. and Suddaby, R. (2006) Institutions and institutional work, in Clegg, S., Hardy, C., Nord, W.R. and Lawrence, T.B. (eds.) The Sage Handbook of Organisation Studies, pp. 215-254. (London: Sage).

Lele, S. (1991) Sustainable development: A critical Review, World Development 19(6), pp. 607-621.

Levy, D.L. (1997) Environmental management as political sustainability, Organisation and Environment, 10(2), pp. 126-147.

Livesey, S. (2001) Eco-identity as discursive struggle: Royal Dutch/Shell, Brent Spar and Nigeria, The Journal of Business Communication, 38(1), pp. 58-91.

Livesey, S. (2002a) The discourse of the middle ground: Citizen Shell commits to sustainable development, Management Communication Quarterly, 15(3), pp. 313349.

Livesey, S. (2002b) Global warming wars: Rhetorical and discourse analytic approaches to ExxonMobil's corporate public discourse, The Journal of Business Communication, 39(1), pp. 117-148.

Livesey, S. and Kearins, K. (2002) Transparent and caring corporations? A study of sustainability reports by The Body Shop and Royal Dutch/Shell, Organisation and Environment, 15(3), pp. 233-258.

Mayhew, N. (1997) Fading to grey: the use and abuse of corporate executive's representational power, in Welford, R. (ed.) Hijacking Environmentalism: Corporate Responses to Sustainable Development. (London: Earthscan). 
Meadowcroft, J. (2000) Sustainable development: A new(ish) idea for a new century? Political Studies, 48, pp. 370-387.

Mebratu, D. (1998) Sustainability and sustainable development: Historical and conceptual review, Environmental Impact Assessment Review, 18, pp. 493-520.

Milne, M.J., Kearins, K.N. and Walton, S. (2006) Creating adventures in wonderland? The journey metaphor and environmental sustainability, Organisation, 13(6), pp. 801-839.

Milne, M.J., Tregidga, H. and Walton, S. (2004) Playing with magic lanterns: the New Zealand Business Council for Sustainable Development and corporate triple bottom line reporting, paper presented at the $4^{\text {th }}$ APIRA conference in Singapore, July 2004.

Neuzil, M. and Kovarik, W. (1996) Mass Media \& Environmental Conflict: America's Green Crusades. (Thousand Oaks, CA: Sage.)

O'Connor, M. (1994) Is Capitalism Sustainable? Political Economy and the Politics of Ecology. (New York: Guilford Press).

Pearce, D. (1993) Sustainable development and developing country economics, in Turner, R.K. (ed) Sustainable Environmental Economics and Management. Principles and Practice. (London: Belhaven Press).

Pearce, D. and Barbier, E. (2000) Blueprint for a Sustainable Economy. (London: Earthscan).

Perelman, C. (1982) The Realm of Rhetoric. (London: Notre dame).

Phillips, N. and Hardy, C. (2002) Discourse Analysis: Investigating Processes of Social Construction, Sage University Papers Series on Qualitative Research Methods, Vol. 50. (Thousand Oaks, CA: Sage).

Porritt, J. (2005) Capitalism as if the world matters. (London: Earthscan).

Potter, J. and Wetherall, M. (1987) Discourse and Social Psychology. Beyond Attitudes and Behaviour. (London: Sage).

Ratner, B.D. (2004) 'Sustainability' as a dialogue of values: Challenges to the sociology of development, Sociological Inquiry, 74(1), pp. 50-69.

Redclift, M. (1987) Sustainable Development: Exploring the Contradictions. (London: Methuen).

Reid, D. (1995) Sustainable Development, An Introductory Guide. (London: Earthscan).

Robinson, J. (2004) Squaring the circle? Some thought on the idea of sustainable development, Ecological Economics 48, pp. 369-384.

Rorty, R. (ed.) (1967) The Linguistic Turn: Recent Essays in Philosophical Method. (Chicago: University of Chicago Press).

Rossi, M.S., Brown, H.S. and Bass, L.W. (2000) Leaders in sustainable development: How agents of change define the agenda, Business Strategy and the Environment 9, pp. 273-286.

Rutherford, P. (2003) Talking the talk: business discourse at the World Summit on Sustainable Development, Environmental Politics, 12(2), pp. 145-150.

Sachs, W. (1993) Global ecology and the shadow of 'development', in Sachs W. (ed.) Global Ecology: A New Arena of Political Conflict. (London: Zed Books).

Schmidheiny, S. (1992) Changing Course: a Global Business Perspective on Development and the Environment. (Cambridge: MIT Press). 
Shrivastava, P. (1994) CASTRATED environment: GREENING and organisation studies, Organisation Studies, 15(5), pp. 705-726.

Shrivastava, P. (1995) The role of corporation in achieving ecological sustainability, Academy of Management Review, 20(4), pp. 936-960.

Spence, C. (2007) Social and environmental reporting and hegemonic discourse, Accounting, Auditing and Accountability Journal, 20(6), pp. 855-882.

Springett, D. (2003a) Business conceptions of sustainable development: a perception from critical theory, Business Strategy and the Environment, 12(2), pp. 71-86.

Springett, D. (2003b) An 'incitement to discourse': Benchmarking as a springboard to sustainable development, Business Strategy and the Environment, 12(1), pp. 1-11.

Strauss, A. and Corbin, J. (1990) Basics of Qualitative Research. Grounded Theory Procedures and Techniques. (London: Sage).

Suddaby, R. and Greenwood, R. (2005) Rhetorical strategies of legitimacy, Administrative Science Quarterly, 50, pp. 35-67.

Tregidga, H. and Milne, M.J. (2006) From sustainable management to sustainable development: a longitudinal analysis of a leading New Zealand environmental reporter, Business Strategy and the Environment, 15, pp. 219-241.

Turner R.K. (1993) Sustainability: principles and practice, in Turner R.K. (ed) Sustainable Environmental Economics and Management. Principles and Practice. (London: Belhaven Press).

United Nations World Commission on Environment and Development [UNWCED] (1987) Our Common Future. (Oxford: Oxford UP).

Vaara E. and Tienari, J. (2002) Justification, legitimization and naturalization of mergers and acquisitions: A critical discourse analysis of media texts, Organisation, 9(2), pp. 275-304.

WBCSD (2002) The business case for sustainable development: Making a difference towards the Earth Summit 2002 and beyond, Corporate Environmental Strategy, 9(3), pp. 226-235.

Welford, R. (ed.) (1997) Hijacking Environmentalism. Corporate Responses to Sustainable Development. (London: Earthscan).

Wetherall, M. (2001) Debates in discourse research, in Wetherall, M., Taylor, S. and Yates, S.J. (eds.) Discourse Theory and Practice. (London: Sage). 